\title{
Evaluation of Eulychnia acida Phil. (Cactaceae) Extracts as Corrosion Inhibitors for Carbon Steel in Acidic Media.
}

\author{
R. Venegas ${ }^{1, *}$, F. Figueredo $^{l}$, G. $_{\text {Carvallo }}{ }^{2}$, A. Molinari $^{l}$, R. $_{\text {Vera }}{ }^{1}$ \\ ${ }^{1}$ Institute of Chemistry, Faculty of Sciences, Pontificia Universidad Católica de Valparaíso, Av. \\ Universidad 330, Placilla (Curauma), Valparaíso, Chile \\ ${ }^{2}$ Institute of Biology, Faculty of Sciences, Pontificia Universidad Católica de Valparaíso, Av. \\ Universidad 330, Placilla (Curauma), Valparaíso, Chile. \\ *E-mail: ricardo.venegas@pucv.cl
}

doi: $10.20964 / 110449$

Received: 7 February 2016 / Accepted: 11 March 2016 / Published: 1 April 2016

The process of pickling to remove corrosion products in metal pipes requires the use of an acidic solution together with corrosion inhibitors to protect the metal. However, the use of synthetic/commercial inhibitors has caused environmental pollution and human health problems. As a result, studies have begun to analyse natural extracts from several different plants as potential corrosion inhibitors, as they are generally more innocuous and/or biodegradable. The present study evaluates the effectiveness of aqueous extracts obtained from Eulychnia acida Phil. (Cactaceae) as potential corrosion inhibitors for carbon steel in acidic media. The total phenolic compound and flavonoid content of the aqueous extracts of the cactus species was determined prior to the experiments. The inhibition efficiency of the extracts obtained by decoction of the external bark, internal bark and medulla of the cactus stems were evaluated by mass loss, demonstrating an efficiency of $90 \%$ at concentrations of 100 and $1000 \mathrm{ppm}$. The polarization curve tests indicate an efficiency of over $80 \%$ inhibition at concentrations of 1000 and $1500 \mathrm{ppm}$. The results show that metabolites present in the extracts act as corrosion inhibitors and are able to promote surface protection by blocking active sites on the metal.

Keywords: corrosion inhibition, cactaceae (copao), carbon steel, acidic media

\section{$\underline{\text { FULL TEXT }}$}

(C) 2016 The Authors. Published by ESG (www.electrochemsci.org). This article is an open access article distributed under the terms and conditions of the Creative Commons Attribution license (http://creativecommons.org/licenses/by/4.0/). 